\title{
Europe tackles huge fraud
}

\section{Regulators scramble to recover millions of euros awarded to fake research projects.}

\section{BY QUIRIN SCHIERMEIER}

S tifling bureaucracy is often blamed for discouraging scientists and businesses from participating in the research programmes of the European Commission (EC). But the commission's notoriously cumbersome procedures and rigid control mechanisms have apparently not prevented a criminal syndicate from conducting a brazen fraud that has siphoned off millions in EC grant funds. Italian authorities and the European Anti-Fraud Office (OLAF) in Brussels, Belgium, have confirmed that they are prosecuting members of a large network accused of pocketing more than $€ 50$ million (US\$72 million) in EC grants for fake research projects. In Milan, Italy, the Finance Police last month charged several individuals in relation to the fraud. In Brussels, meanwhile, the EC has terminated four collaborative projects in information technology, and excluded more than 30 grant-winners from participation in around 20 ongoing projects. Investigations are still under way in the United Kingdom, France, Greece, Austria, Sweden, Slovenia and Poland.

"We don't have any records of [previous] fraud at such a scale," says David Boublil, the commission's spokesman for taxation, customs, anti-fraud and audit. While investigations continue, Italian prosecutors and OLAF will not disclose the names of the suspects, or the research projects with which they were involved.

The fraud has been conducted in a "highly sophisticated manner, resembling money laundering", by means of a cross-border network of fictitious companies and subcontractors, says Pavel Bořkovec, a spokesman for OLAF. Several project coordinators stand accused of having claimed inflated costs, or expenses for non-existent research activities and services, he says.

"The projects were apparently organized with the sole intention to deceive the commission and its control mechanisms," says Boublil. To make them seem legitimate, grant applications included the names of real

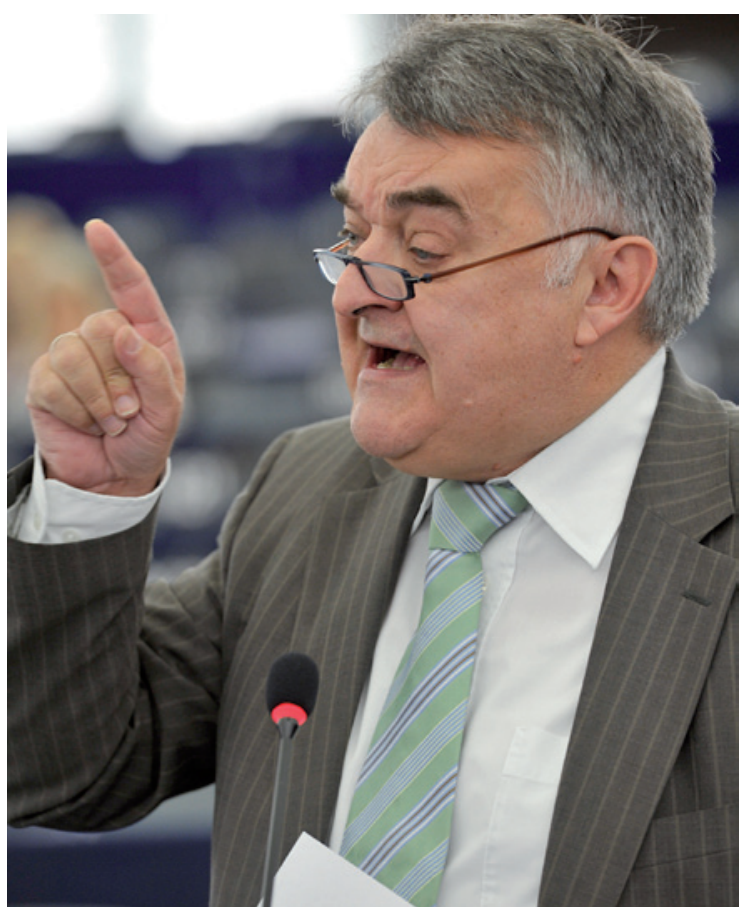

Herbert Reul, the European Parliament research committee chair, hopes a case of fraud will not hinder easing of grant applications. research projects. But the commission does extensive checks on project partners, including companies, which are meant to catch largescale fraud. The success of the fraud suggests that those involved were unusually familiar with weaknesses in the EC's procedures, and adept at forging legal documents.

Boublil insists that the commission has learned lessons from the case. All departments handling research grants - including the EC's Information Society and Media Directorate General, which oversaw the terminated projects - are now trained to look out for the methods used by the network. Guidelines for evaluating projects and their partners are set to be updated. The EC has already recovered $€ 10$ million of the money, and will seek to recover the rest through the courts, Boublil says.

The commission is currently developing a multibillion-dollar 'Common Strategic Framework' which, from 2014, will combine its various funding streams into a single channel for all research and innovation funding. Concerned about the burden of Brussels bureaucracy, several thousand European scientists signed a petition this year (www.trustresearchers.eu) calling for the framework to be "based on mutual trust and responsible partnering". Some now fear that the fraud could hamper efforts to cut red tape.

"I'm worried that some will argue that what has happened proves that we need more rather than less control," says scientists, established research institutes and existing companies, he says. But in most cases the alleged project partners were included without their knowing.

Insiders in Brussels say that rare cases of minor financial dishonesty, from inflated invoices to smaller cases of embezzlement, are regarded as unavoidable in large collaborative
Herbert Reul, chair of the European Parliament's committee on industry, research and energy, which supports the simplification of the EC's funding procedures. "I sincerely hope that this will not happen. Actually, it is a good sign that this worrying attempt at deceiving the commission has been discovered and will be punished."
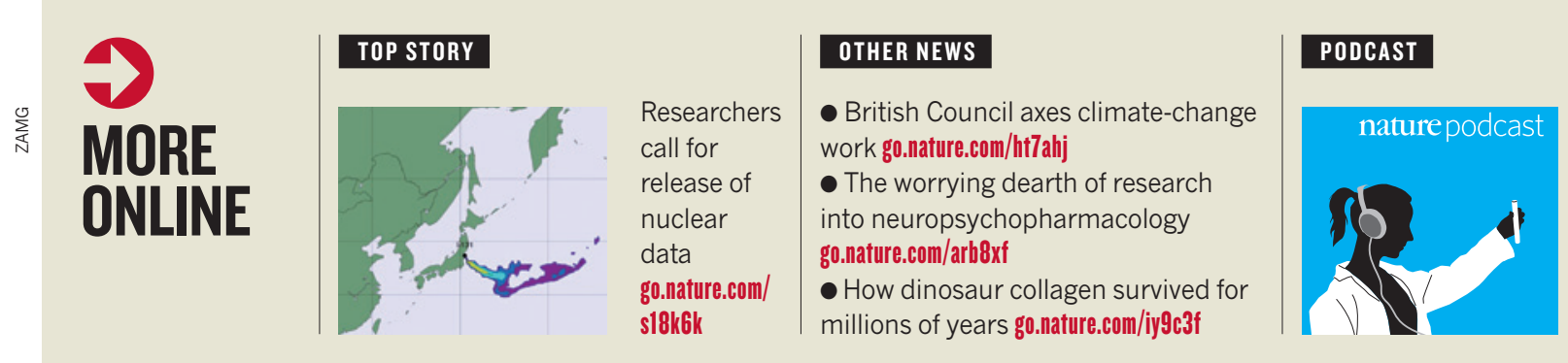

Voyager 1 reports back, and the rap guide to evolution go.nature.com/ qeaijm 